\title{
On the Photosysthesis of Natural Phytoplankton under Field Conditions
}

\author{
by Shun-ei IcHIMURA* \\ 市村俊英*：自然状態に抢ける植物性プランクトンの光合成
}

Received December 28, 1957

In the last decade, the problem in limnology has been focused upon the biological production. As all life in a lake depends directly or indirectly upon the organic matter synthesized by plants, the first step in the study of biological production in a lake should start from the photosynthesis of phytoplankton, on which the primary production is based. Regarding the photosynthesis of algae, numerous studies have been reported by many plant physiologists. However, they have concentrated their studies mainly on the analyses of mechanism of photosynthesis, and the experiments were performed with pure cultured algae under opitimal condition in laboratory. On the contrary, the informations on photosynthesis of phytoplankton under natural condition are still inadequate for ecological elucidation of productivity of lakes. Therefore, for the ecological study of production of lakes, it is necessary to clarify the characters of photosynthesis proceeding in nature more quantitatively. The following study was undertaken to fill up these gaps.

\section{Methods}

Photosynthesis was measured by the "in situ" method. Sample water was taken up from the surface or various depths of a lake, then filled into clear and dark glass bottles of $100 \mathrm{ml}$. and finally the bottles were lowered down to the depth from which the water was taken. After certain hours, the increase or decrease of oxygen dissolved in the water of bottles was determined by Winkler's method. The amount of real photosynthesis was obtained by adding the respiration measured in the dark bottle to the net photosynthesis measured in the clear one. The suspension time did not exceed 6 hours in all cases (refer to Verduin, J. 1956, Ichimura and Saijo, in press). The total photosynthesis in a day was estimated as the double amount of a half day photosynthesis measured from noon to sunset. Density of phytoplankton in the water was determined by pigment analysis after filtration with two sheets of filter paper (Toyo, No. 101), and indicated as the chlorophyll amount (see Gessner, 1944, Hogetsu and Ichimura 1954). As seen in Table 1, the photosynthetic capacity of filtrated water was so low and so greatly departed from the initial capacity of

* Botanical Institute, Faculty of Science, Tokyo University of Education, Otsuka, Tokyo, Japan. 東京教育大学理部部倠物受教室 
Table 1. Comparison of photosynthetic activity between raw water and filtrated water which was filtrated through two sheets of filter paper (Tōyō, No. 101) with a suction apparatus.

\begin{tabular}{|c|c|c|}
\hline Lake & Dominant phytoplankter & $\begin{array}{c}\text { Photosynthetic activity } \\
\mathrm{O}_{2} \mathrm{mg} \cdot / 1 / \text { day } \\
\text { Raw water Filtrated water }\end{array}$ \\
\hline $\begin{array}{l}\text { Jönuma } \\
\text { Kasumigaura } \\
\text { Teganuma }\end{array}$ & $\begin{array}{l}\text { Chlamydomonas sp. } \\
\text { Microcystis } \mathrm{sp} . \\
\text { Fragilaria } \mathrm{sp} \text {. }\end{array}$ & $\begin{array}{ll}1.075(1.00) & 0.114(0.106) \\
0.847(1.00) & 0.082(0.097) \\
0.701(1.00) & 0.046(0.066)\end{array}$ \\
\hline
\end{tabular}

raw water that the phytoplankton which passed through the two sheets of filter paper may be less than 10 per cent of the total phytoplankton in the sample water. In the present study, the photosynthesis of phytoplankton is expressed by the amount of oxygen evolved per mg. chlorophyll corrected for 10 per cent error.

\section{Results}

A. Daily and vertical change in the rate of photosynthesis.

Variation of illumination in a day affects on the photosynthetic rate remarkably. Fig. 1 shows the characteristic feature of the change of photosynthetic rate at various depths during the course of a day. Data were obtained at Lake Teganuma on a clear day in May. The transparency measured with Secchi's disc was about 1.3 metres. The material used for this experiment was collected with a plankton net from surface of the lake and its photosynthesis was measured at various depths of the lake.

In the morning hours the highest rate was measured at the surface, but in midday

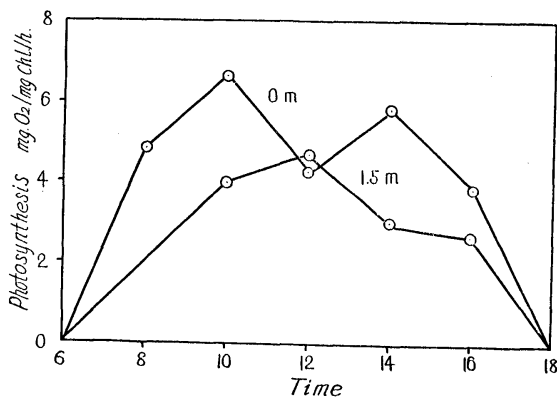

Fig. 1. Daily change in photosynthetic rate of phytoplankton in Lake Teganuma. that was obtained at deeper depth, because the photosynthesis in the upper layer was interfered by too intense sun light. The highest rate again shifted at the surface in the afternoon. These photosynthesis curves with two peaks are similar to that described by Jenkin (1937), and resemble to those obtained in land plants. Of course, the form of photosynthesis curves obtained at each depth differs from each other according to the light intensity prevailing on the lake surface and the transparency. For instance, the photosynthesis curve obtained at the surface on cloudy day did not show two peaks. Table 2 indicates the variation of the daily total amount of photosynthesis with increasing water depth. The maximum rate was generally found at some depth below the surface on clear day, and on cloudy day it shifted upwards. In winter, solar illumination is so low that the maximum rate was always found at the surface. The direct relationship between light intensity and photosynthetic rate in lake was discussed with the data of light intensity measured photoelectrically at 
Table 2. Photosynhesis rate of phytoplankton at various depths measured in various seasons. The value is expressed by $\mathrm{O}_{2} \mathrm{mg}$. per chlorophyll mg. per day.

\begin{tabular}{|c|c|c|c|c|c|c|c|c|}
\hline $\begin{array}{l}\text { Lake } \\
\text { Weather } \\
\text { Month }\end{array}$ & \multicolumn{2}{|c|}{$\begin{array}{c}\text { Kasumigaura } \\
\text { Cloudy }\end{array}$} & \multicolumn{2}{|c|}{$\begin{array}{c}\text { Nakanuma } \\
\text { Sunny }\end{array}$} & \multicolumn{2}{|c|}{$\begin{array}{l}\text { Suwa } \\
\text { Sunny }\end{array}$} & \multicolumn{2}{|c|}{$\begin{array}{c}\text { Teganuma } \\
\text { Sunny }\end{array}$} \\
\hline Depth & & & & & & & & \\
\hline $0 \mathrm{~m}$ & 36 & 15 & 37 & 21 & 30 & 18 & 4 & 12 \\
\hline $1 \prime \prime$ & 7 & 3 & 67 & 26 & 23 & 10 & 7 & 9 \\
\hline $2 \prime \prime$ & 3 & 2 & 79 & 15 & 10 & 5 & 3 & - \\
\hline $3 \prime \prime$ & 2 & - & 59 & 8 & 7 & 4 & - & - \\
\hline $4 \prime \prime$ & - & - & 16 & 3 & 2 & - & - & - \\
\hline
\end{tabular}

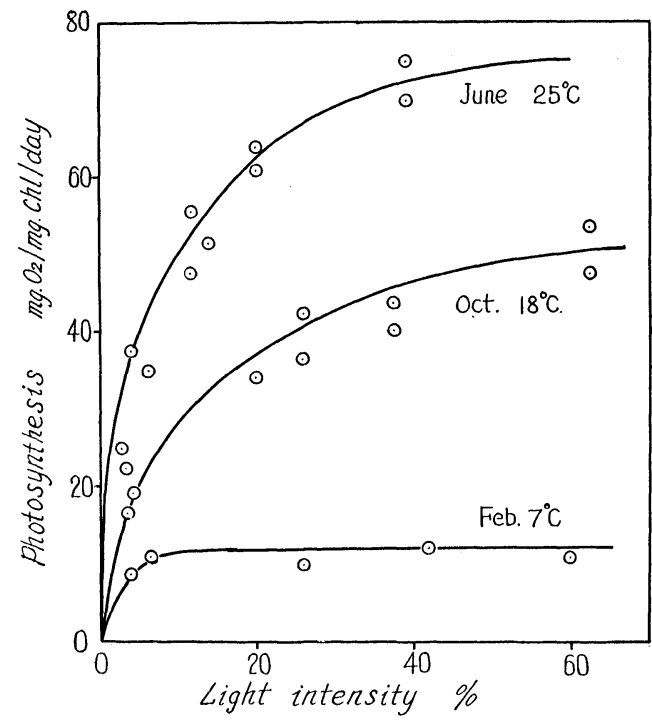

Fig. 2. Relation between photosynthesis of phytoplankton and light intensity measured under field condition. various depths, at which the bottle was suspended. Results obtained at Lake Nakanuma in several seasons are shown in Fig. 2. The light-photosynthesis curve is similar to the well-known light photosynthesis curve in algae which has been obtained in laboratory by many investigators. The light saturation of photosynthesis was found at about 50 per cent of initial illumination. Further increase of illumination caused little change or even inhibition in photosynthetic rate.

B. Seasonal change in rate of photosynthesis

The photosynthesis of phytoplankton showed considerable variation in the course of year. The results gained at Lake Nakanuma during 1950-1951, and those gained at Lake Teganuma during 1956-1957, are shown in Fig. 3. Measurement were performed two or three times a month, and the monthly mean of photosynthesis maximum in each " in situ" experiment was taken. The photosynthetic rate of phytoplankton obtained at Lake Nakanuma showed two marked pulses in early summer and in autumn. Namely, the photosynthetic activity began to increase on March and rapidly reached a large early summer value, and thereafter decreased during summer. It, however, increased again in early autumn and reached a large autumn value. During winter the photosynthetic rate exhibited very low or negative value. The feature of the curve obtained at Lake Teganuma, which is very shallow water and where higher water plants are vigorously growing, accord- 
ed with that of Lake Nakanuma, but the extreme increase in autumn did not appear. It is interesting to note that the photosynthetic activity is roughly propotional to the amount of solar energy falling on the surface of lake. However, in a few cases exceptionally high photosynthetic activity in winter was observed, for example, at Lake Suwa in December (Hogetsu and Ichimura 1954), and similar phenomena were reported by Verduin (1956), too. These differences are obviously attributed to water temperature, light condition, nutrient concentration, character of algae, etc., in each lake. The author will touch these phenomena in other paper.

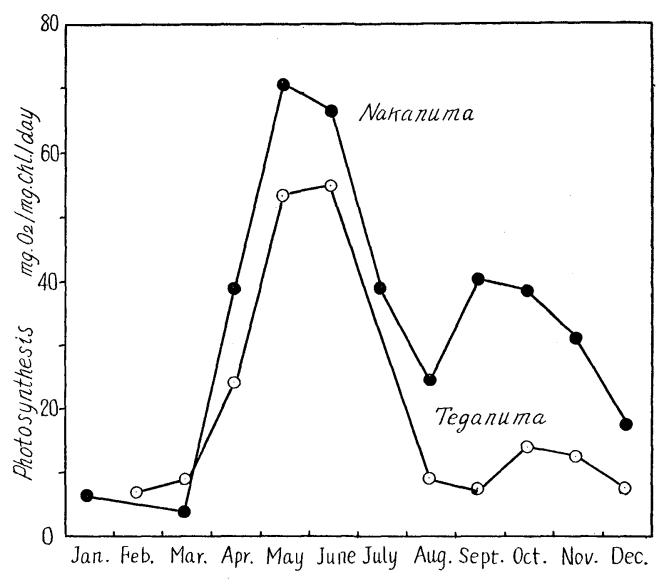

Fig. 3. Seasonal change in photosynthetic rate. Data in the diagram were obtained at 1 metre depth in each lake.

\section{Maximum photosynthetic activity of phytoplankton under field condition}

It is difficult to determine the maximum photosynthetic rate under natural condition, as the photosynthesis is limited not only by the external factors but also by the internal ones. The maximum rate in this work represents only the average of high values measured in the course of a year. The highest values obtained at the depth of optimal light intensity in various lakes summarized in Table 3. Although

Table 3. Maximum photosynthetic rate of phytoplankton measured in the course of year at several lakes. Photosynthesis was expressed by $\mathrm{O}_{2} \mathrm{mg}$. per chlorophyll mg. per day.

E: Eutrophic lake, M: Mesotrophic lake, O: Oligotrophic lake

\begin{tabular}{|c|c|c|c|c|}
\hline Lake & \multicolumn{2}{|c|}{ Date } & $\begin{array}{l}\text { Photosynthetic rate } \\
\mathrm{O}_{2} \text { mg./chl. mg./day }\end{array}$ & Dominant phytoplankter \\
\hline Jōnuma(E) & Oct. & 27,1956 & 112.8 & Chlamydomonas sp, \\
\hline Suwa(E) & Oct. & 18,1954 & 105.0 & Microcystis sp. \\
\hline Kasumigaura(E) & Nov. & 23,1956 & 95.7 & Microcystis sp. \\
\hline Nakanuma(E) & June & 5,1952 & 76.9 & Fragilaria sp. \\
\hline Ushikunuma(E) & June & 20,1954 & 67.0 & Desmid \\
\hline Teganuma(E) & July & 15,1954 & 65.2 & Melosira italica \\
\hline Shinseiko(M) & July & 11,1956 & 44.4 & Chlorophyceae \\
\hline Yamanakako(M) & Sept. & 8, 1956 & 42.0 & Botoryococcus sp. \\
\hline Akagi-Onuma $(\mathrm{O})$ & July & 11, 1955 & 25.0 & Asterionela sp. \\
\hline Ashinoko(O) & July & 22,1957 & 19.0 & Melosira sp. \\
\hline
\end{tabular}


phytoplankton in extremely eutrophicated lake or in cultured algae sometimes showed higher rate than $100 \mathrm{mg} \mathrm{O}_{2} / \mathrm{chl}$. mg./day, natural phytoplankton in eutrophic lakes seems generally to show a somewhat lower rate than this.

The average maximum rate was situated between $80 \mathrm{mg}$ and $90 \mathrm{mg} \mathrm{O}_{2} / \mathrm{chl} . \mathrm{mg} /$ day in eutrophic lake. $40 \mathrm{mg}$., and $50 \mathrm{mg}$. in mesotrophic lake, and $10 \mathrm{mg}$. and $20 \mathrm{mg}$. in oligotrophic lake. Because of lack of data on the diurnal change of photosynthetic rate, the maximum rate of per hour cannot sufficiently be indicated in this paper. For the purpose of reference, a few results were indicated in Table 4, in which

Table 4. Maximum photosynthetic rate of phytoplankton per hour measured at some lakes.

\begin{tabular}{|c|c|c|c|}
\hline Lake & Date & $\begin{array}{l}\text { Photosynthetic rate } \\
\mathrm{O}_{2} \text { mg./chl. mg./hr. }\end{array}$ & $\begin{array}{c}\text { Dominat } \\
\text { Phytoplankter }\end{array}$ \\
\hline Jōnuma & Sept. $\quad 18,1956$ & 8.2 & Euglena sp. \\
\hline Kasumigaura & 21,1956 & 7.2 & Microcystis sp. \\
\hline Nakanuma & 30,1957 & 7.7 & Eudorina sp. \\
\hline Teganuma & 25,1956 & 6.8 & Melosira sp. Eudorina sp. \\
\hline Kawaguchiko & 28,1955 & 4.6 & Melosira sp. \\
\hline Ashinoko & 24,1957 & 1.7 & Melosira sp. \\
\hline
\end{tabular}

the data represent the maximum value in the course of a day. Though the photosynthetic rate was measured with various species taken from eutrophic lakes, those algae showed similar photosynthetic activity per unit chlorophyll, and $7.8 \mathrm{mg} . \mathrm{O}_{2} /$ ch!. mg./hr. may be considered as an average maximum rate under natural condition. This value is well accordance with the results reported by other authors (Manning and Juday 1941, Gessner 1944). It is noticeable that the maximum photosynthetic rate based on unit chlorophyll falls nearly same values without regard to difference of phytoplankton species.

Therefore, the difference of photosynthetic activity in different species may sometimes be negligible with some limitation, if the photosynthetic rate is discussed on the basis of unit chlorophyll. These things have also been confirmed through experiments with various cultured algae (Ryther 1956, Ichimura, in press).

D. Relation of the photosynthetic capacity of lake water to the phytoplankton concentration in the water

In recent years, Hogetsu and Ichimura (1954) and Ryther (1957) performed the computation of the primary production from chlorophyll and light data. Assuming a strict proportionality batween the photosynthetic capacity and the chlorophyll amount, it may be possible to deduce the primary production of phytoplankton population from the latter. Concerning this, an experiment was carried out. A part of the phytoplankton collected from water near surface with a plankton net was suspended in various concentration in bottles filled with filtrated surface water. The 
bottles were suspended at 1 metre below the surface of water for 6 hours. Fig. 4 indicates the results of the experiment at Lake Nakanuma in July. Linear correlation between those two values, with limitation under $0.1 \mathrm{mg}$. chlorophyll/1, can be seen. This was also confirmed by Ryther (1956), though his experiment was done not in field, but in laboratory with cultivated algae. The highest chlorophyll concentration found in various Japanese lakes was in a range of $0.1 \mathrm{mg} .-0.15 \mathrm{mg}$. per liter and the photosynthetic capacity (gross photosynthesis) of these waters was $8 \mathrm{mg}$. $-14 \mathrm{mg}$. of $\mathrm{O}_{2}$ per litre and day, namely the maximum photosynthesis in these waters could reach the

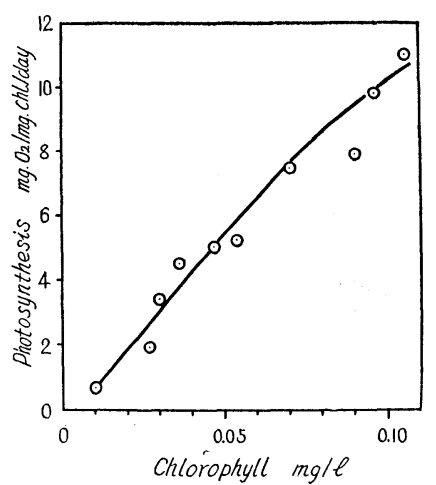

Fig. 4. Photosynthesis of phytoplankton in lake as a function chlorophyll concentration values of $90 \mathrm{mg} . \mathrm{O}_{2} / \mathrm{chl} . \mathrm{mg}$./day. Manning and Juday (1941) reported that in water bloom the maximum photosynthesis per unit chlorophyll was usually not so high as expected, but under ordinary condition, the phytoplankton population is not so large as the density effect acts remarkably on the depression of photosynthetic capacity. The chlorophyll amount, therefore, can be used as a measure of productive capacity of a lake. It seems sometimes to be not proper to compare the productivity of lakes on the basis of chlorophyll concentration alone, because the photosynthetic activity of phytoplankton is determined by many factors. However, if the environmental factors, the productive structure of community, deterioration of phytoplankton, etc., are properly considered, the chlorophyll amount will be very useful as an index of photosynthetic capacity.

E. Correlation between the productivity and the growth rate of phytoplankton population

In the early papers (1954a. 1954b), we analysed the seasonal change in standing crop of phytoplankton on the basis of the productivity, and it was confirmed that there was a parallelism between the productivity and the growth rate of phytoplankton. Such a parallelism has also been proved experimentaly by Talling (1955).

The present study proved the results of these works with field experiments. The results obtained at

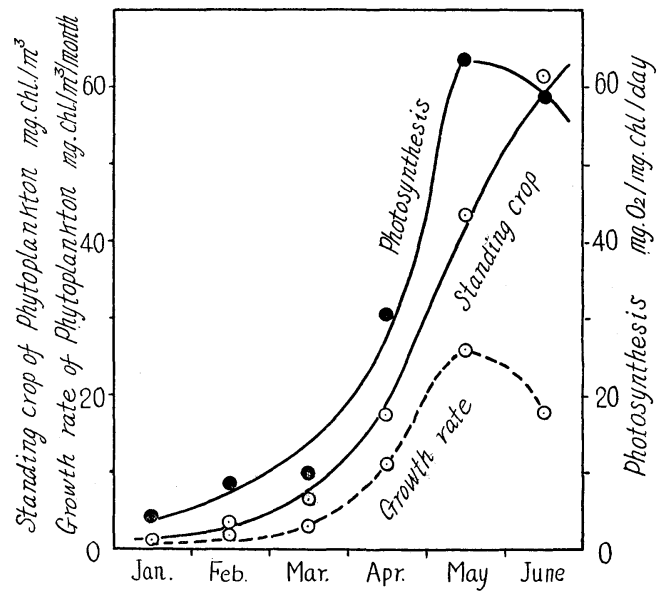

Fig. 5. Relation between productivity and growth rate of phytoplankton population.

the depth of 1 metre in Lake Nakanuma in earlier part of 1956 are shown in Fig. 5. The feature of seasonal change in photosynthetic rate agreed fairly well with that 
of growth rate indicated by the increase of chlorophyll per month. As seen in the figure, however, there was a little discrepancy between variation curves of photosynthesis rate and standing crop during early summer. The photosynthetic rate and the growth rate were the highest in May and declined gradually thereafter, while the standing crop did not attain to the highest value at this time and increased until the end of July. Similar results have also been reported by Penfound (1956) who measured periodically the standing crop of Typha latifolia. To make clear the cause of the seasonal variation of phytoplankton, it seems to be necessary to analyse the proportionality between the photosythetic rate and the growth rate on physiological basis in future.

\section{Summary}

(1) Photosynthesis of natural phytoplankton was studied under field condition. The amount of phytoplankton was determined by chlorophyll content of lake weter and the photosynthetic rate was expressed by oxgen in mg. evolved by one $\mathrm{mg}$. chlorophyll.

(2) The effect of diurnal change of light intensity on the photosynthesis was remarkable. The light saturation of the photosynthesis was found at about 50 per cent of the surface light and the further increase of light caused even inhibition in photosynthesis.

(3) The photosynthetic rate of phytoplankton varied considerably in the course of a year and showed two marked pulses in early summer and in autumn. However, the feature of variation of photosynthesis much differs with lake types.

(4) As the maximum photosynthetic activity under field condition, $80 \mathrm{mg} .-90 \mathrm{mg}$. $\mathrm{O}_{2}$ / chl.mg./day in eutrophic lake, $30 \mathrm{mg} .-40 \mathrm{mg} . \mathrm{O}_{2} / \mathrm{chl} . \mathrm{mg}$./day in mesotrophic lake and $10 \mathrm{mg} .-20 \mathrm{mg} . \mathrm{O}_{2} / \mathrm{chl}$. mg./day in oligotrophic lake were measured respectivelly.

(5) The photosynthetic capacity relates with the amount of chlorphyll fairly strictly.

(6) Parallelism between the photosynthetic rate and the growth rate of phytoplankton population was recognized.

The author wishes to express his thanks to Prof. M. Monsi and Prof. K. Hogetsu for their instructive guidance and advice. This work was surported in part by a grant in Aid for Fundamental Scientific Research given to Prof. K. Hogetsu from the Ministry of Education.

\section{References}

1) Ichimura, S., Jap. Jour. Bot. 14: 269 (1954 a). 2) Gessner, Fr., Arch. Hydrobiologie 40:686 (1944). 3) Hogetsu, K. and Ichimura, S., Jap. Jour. Bot. 14: 280 (1954 b). 4) Jenkin, P., J. Marine Biol. Assoc. United Kingdom 22: 301 (1937). 5) Manning, W. M., and Juday R. E., Trans. Wis. Acad. Sic., Arts Lett. 33: 363 (1941). 6) Penfound $W_{M}$. T., Limnology and Oceanography i : 92 (1956). 7) Ryther, J. H., Limnology ond Oceanography 1: 72 (1956). 8) Talling, J. F., Ann. Bot. 19: 329 (1955). 9). Verduin, J., Ecology 37: 40 (1956). 